\title{
DUKUNGAN SUAMI TERHADAP PEMILIHAN KONTRASEPSI INTRAUTERIN DEVICE DI WILAYAH KERJA PUSKESMAS MAMBURUNGAN
}

\author{
Yuni Retnowati ${ }^{1}$, Doris Novianti ${ }^{2}$, Kiku Wulandary $^{3}$ \\ 1,2\&3 Fakultas Ilmu Kesehatan Universitas Borneo Tarakan \\ *Email:yuni100682@gmail.com
}

\begin{abstract}
Abstrak
Dukungan suami sangatlah berdampak positif bagi keluarga, terlebih terhadap pasangannya, karena adanya dukungan suami terutama dalam pemilihan IUD, maka istri akan merasa yakin dalam memilih dan selama pemakaiannya istri tidak akan khawatir karena suami sudah mendukung. Penelitian ini bertujuan untuk mengetahui adanya hubungan dukungan suami terhadap pemilihan kontrasepsi IUD. Jenis penelitian yang digunakan adalah deskriptif kolerasi yang menggunakan rancangan cross sectional. Populasi dalam penelitian ini adalah seluruh akseptor kb di wilayah kerja Puskesmas Mamburungan. Teknik sampel menggunakan Proportionate Stratified Random Sampling dengan jumlah responden 54 orang. Pengumpulan data dilakukan menggunakan instrument penelitian berupa kuesioner baik pada dukungan suami maupun pemilihan kontrasepsi. Pengelolaan dan analisa data menggunakan program SPSS dan selanjutnya disajikan dalam bentuk tabel dan narasi, dengan menggunakan tes statistik dengan tingkat kemaknaan $\alpha<0,05$. Hasil penelitian terhadap responden pada dukungan suami diperoleh hasil yang tidak mendukung sebanyak 33 orang $(61,1 \%)$ dan yang mendukung sebanyak 21 orang $(38,9 \%)$. Pemilihan kontrasepsi IUD 20 orang $(37,0 \%)$ dan yang Non IUD sebanyak 34 orang $(63,0 \%)$. Pada uji statistik diperoleh hasil $\mathrm{p}=0,006$ yang berarti terdapat hubungan dukungan suami terhadap pemilihan kontrasepsi IUD. Disarankan pada penelitian selanjutnya dapat meneliti variabel-variabel lain yang mempengaruhi dukungan suami terhadap pemilihan kontrasepsi IUD.
\end{abstract}

Kata Kunci : Dukungan Suami, Pemilihan Kontrasepsi, IUD

Abstract

Husband Support On Contraception Selection of Intrauterin Device In Puskesmas Mamburungan Work Area. Husband's support has significantly positive impact for the family, especially to the spouse, because of the husband support especially in the selection of IUD, then the wife will feel confident in choosing and during the utilization, the wife will not worry because the husband is supportive. This study aims to determine the relationship of husband support to IUD contraceptive selection. The type of research used is descriptive correlation using cross sectional design. The population in this research is all family planned (contraception) acceptor in the working area of Puskesmas Mamburungan. The sampling technique use Proportionate Stratified Random Sampling with the number of respondents 54 people. The data were collected by using questionnaires in both husband support and contraceptive selection. Management and data analysis apply SPSS program and subsequently presented in the form of tables and narration, by using statistical test with significance level $\alpha<0,05$. The result of the research on the respondents on the support of husband obtained the result that did not support as many as 33 people $(61,1 \%)$ and supporting as many as 21 people (38.9\%). Election of contraception IUD 20 people (37,0\%) and Non-IUD 34 people $(63,0 \%)$. In the statistical test results obtained $p=0.006$ which means there is a relationship of support of husband to IUD contraception election. It is suggested for the next study to examine other variables that affect the support of husband to IUD contraceptive election.

Keywords: Husband Support, Contraception Selection, IUD 


\section{Pendahuluan}

Pertumbuhan penduduk di Indonesia terus meningkat setiap tahunnya. Hasil proyeksi Badan Pusat Stastistik (BPS) menunjukkan jumlah penduduk Indonesia pada tahun 2010 mencapai 231,4 juta dan menjadi 249,7 juta pada tahun 2015. Jika laju pertumbuhan Penduduk (LPP) di Indonesia saat ini stagnan pada 1,3\%, maka diperkirakan jumlah penduduk Indonesia akan meningkat dua kali lipat setiap 50 tahun. Kenaikan jumlah penduduk berdampak pada persoalan ketahanan pangan, pemenuhan kebutuhan energi, pengendalian lingkungan hidup dan rendahnya Indeks Pembangunan Manusia (IPM) Indonesia. Saat ini Indonesia berada pada peringkat 108 dari 162 negara (BKKBN, 2011).

Pemerintah dalam rangka upaya pengendalian jumlah penduduk, menerapkan program Keluarga Berencana (KB) sejak tahun 1970 dengan tujuan untuk memenuhi kebutuhan masyarakat akan pelayanan KB dan kesehatan reproduksi yang berkualitas, menurunkan tingkat atau angka kematian ibu, bayi dan anak, serta penanggulangan masalah kesehatan reproduksi dalam rangka membangun keluarga kecil berkualitas. (BKKBN, 2011).

$$
\text { Keluarga Berencana }
$$
merupakan suatu program pemerintah yang dirancang untuk menyeimbangkan antara kebutuhan dan jumlah penduduk. Program keluarga berencana oleh pemerintah adalah agar keluarga sebagai unit terkecil kehidupan bangsa diharapkan menerima Norma Keluarga Kecil Bahagia dan Sejahtera (NKKBS) yang berorientasi pada pertumbuhan yang seimbang. Gerakan Keluarga Berencana Nasional Indonesia telah berumur sangat lama yaitu pada tahun 70-an dan masyarakat dunia menganggap berhasil menurunkan angka kelahiran yang bermakna. Perencanaan jumlah keluarga dengan pembatasan yang bisa dilakukan dengan penggunaan alat-alat kontrasepsi atau penangulangan kelahiran seperti kondom, IUD dan sebagainnya. Keluarga berencana adalah salah satu usaha untuk mencapai kesejahteraan dengan jalan memberikan nasihat perkawinan, pengobatan kemandulan dan penjarangan kehamilan. (Irianto, 2014).

IUD merupakan salah satu alat kontrasepsi metode kontrasepsi yang reversible, berjangka panjang dan dapat 
dipakai 5-10 tahun. IUD merupakan metode kontrasepsi yang sangat efektif dengan $\quad 0,6-0,8 \quad$ kehamilan/100 perempuan atau satu kegagalan dalam 125-170 kehamilan dan IUD dapat segera efektif setelah pemasangan. IUD memiliki efektifitas sebesar $99,7 \%$. Efektifitas KB IUD ini lebih baik dibandingkan $\mathrm{KB}$ jenis lain, seperti koitus interuptus efektifitasnya mencapai $81 \%$, kondom efektifitasnya mencapai $\quad 85 \%, \quad$ diagfragma efektivitasnya mencapai $82 \%$, spermisida efektivitasnya mencapai $80 \%$, pil efektivitasnya mencapai $97 \%$, suntik mencapai $95 \%$ dan implant mencapai 97\%. (Rahmayani, 2015).

IUD dapat diterima masyarakat dunia, termasuk Indonesia dan menempati peringkat ketiga dalam pemakaian. Keuntungan penggunaan IUD yaitu dapat diterima masyarakat dengan baik, pemasangan tidak memerlukan teknis medis yang sulit, Kontrol medis yang ringan, penyulit tidak terlalu berat, dan pulihnya kesuburan setelah IUD dicabut berlangsung baik (Fatimah, 2013). Terdapat beberapa kerugian dari penggunaan IUD, seperti waktu mentruasi yang memanjang, perdarahan saat mentruasi, nyeri abdomen, paparan infeksi, perasaan tidak nyaman, demam, menggigil dan kehilangan benang pengikat. (Rahmayani, 2015)

Rendahnya minat terhadap pemakaian kontrasepsi IUD tentunya tidak lepas dari rendahnya dukungan suami untuk menggunakan alat kontrasepsi tersebut. Sehingga sangat perlu pemahaman yang baik tentang kontrasepsi IUD bagi pasangan usia subur. Dukungan suami merupakan salah satu variabel sosial budaya yang sangat berpengaruh terhadap pemakaian alat kontrasepsi bagi kaum wanita sebagai istri secara khusus dan didalam keluarga secara umum. (Depkes, 2000).

Penggunaan IUD dipengaruhi oleh beberapa faktor. salah satu penelitian. Dilakukan di Sumatera Utara bahwa mayoritas responden penelitiannya berusia diatas $35(61,7 \%)$, berpendidikan SMA $(61,7 \%)$, mempunyai satu sampai dua orang anak $(51,1 \%)$, memiliki pengetahuan yang kurang tentang IUD (80,9\%), menyatakan bahwa efek samping merupakan salah satu faktor yang menyebabkan responden tidak menggunakan IUD $(59,6 \%)$, bersikap negatif terhadap IUD $(57,4 \%)$ dan tidak diberi dukungan oleh suami dan petugas KB untuk menggunakan IUD (72,3\%). (Fatimah, 2013). 
Dukungan suami merupakan sifat interaksi yang berlangsung dalam berbagai hubungan sosial individu, yaitu istri. Sudah menjadi tradisi kalau segala sesuatu harus dengan persetujuan suami atau yang berkuasa di rumah. Hal ini sangat mempengaruhi seorang ibu untuk menjadi seorang akseptor. Keluarga sangat berperan penting dalam pemilihan alat kontrasepsi, karena jika ada salah satu keluarga yang tidak setuju, ibu akan mempertimbangkan ulang pilihannya misalnya ibu memilih IUD dan sebagian besar ibu akan ikut dengan keputusan suami, atau anggota keluarga yang lain.

Perilaku penggunaan kontrasepsi dipengaruhi oleh tiga faktor, yaitu faktor predisposing (dari diri sendiri) yang mencakup pengetahuan, sikap umur, jumlah anak, persepsi, pendidikan, ekonomi dan variabel demografi. Faktor enabling (pemungkin) yang mencakup fasilitas penunjang, sumber informasi dan kemampuan sumber daya. Dan faktor reinforcing (penguat) yang mencakup dukungan keluarga/tokoh masyarakat. (Irianto, 2014).

Jumlah peserta KB baru di Indonesia secara nasional pada Agustus 2011 sebanyak 687.715 orang. Metode kontrasepsi yang paling banyak digunakan adalah suntik sebanyak 356.532 orang $(51,84 \%)$, pil sebanyak 211.220 orang $(30.71 \%)$, kondom sebanyak 58.875 orang $(8,56 \%)$, IUD sebanyak 30.455 orang $(4,43 \%)$, implant sebanyak 24.924 orang $(3,62 \%)$, MOW sebanyak 5.357 orang $(0,78 \%)$ dan MOP sebanyak 352 orang $(0,05 \%)$. Data tersebut menunjukkan bahwa pengguna KB IUD menempati posisi keempat setelah metode $\mathrm{KB}$ suntik, pil dan kondom. Alasan perempuan lebih suka menggunakan $\mathrm{KB}$ hormonal yaitu cara pemakaiannya cepat, efek sampingnya lebih sedikit dan perempuan tidak perlu merasa takut saat menggunakannya. (BKKBN, 2011). Hasil studi pendahuluan yang dilakukan peneliti terhadap yang menggunakan alat kontrasepsi ditemukan beberapa orang menggunakan IUD dan beberapa ibu menggunakan KB jenis lain. Ibu tidak menggunakan IUD disebabkan karena ibu merasa takut menggunakan IUD dan takut pada saat pemasangan, tidak dizinkan oleh suaminya, ibu merasa takut dan khawatir benang IUD dapat terlepas atau keluar dengan sendirinya, serta ibu tidak mengetahui ada jenis metode kontrasepsi IUD. Berdasarkan latar belakang di atas maka penulis ingin melakukan penelitian tentang 
"Hubungan dukungan suami terhadap pemilihan kontrasepsi Intra Uterin Device”. Sedangkan tujuan penelitian ini untuk mengetahui adanya hubungan

\section{Metode}

Dalam penelitian menggunakan jenis penelitian deskriptif kolerasi yaitu penelitian yang menjelaskan hubungan antara variabel-variabel melalui pengujian hipotesa yang telah dirumuskan dan mencoba menggali ada hubungan atau tidak pada penelitian tersebut, yang bertujuan untuk mengetahui adanya hubungan dukungan suami terhadap pemilihan kontrasepsi IUD. Jenis penelitian yang digunakan adalah deskriptif kolerasi yang menggunakan rancangan cross sectional. Populasi dalam penelitian ini adalah seluruh akseptor $\mathrm{kb}$ di wilayah

\section{Hasil Penelitian}

Tabel 4.1 Distribusi Frekuensi Berdasarkan Dukungan Suami

\begin{tabular}{ccc}
\hline Dukungan & Frekuensi & Persentasi \\
\hline Mendukung & 21 & 38.9 \\
Tidak & 33 & 61.1 \\
Mendukung & & \\
\hline Total & 54 & 100.0
\end{tabular}

dukungan suami terhadap pemilihan kontrasepsi Intra Uterin Device di wilayah kerja Puskesmas Mamburungan Kota Tarakan.

kerja Puskesmas Mamburungan. Teknik sampel menggunakan Proportionate Stratified Random Sampling dengan jumlah responden 54 orang. Pengumpulan data dilakukan menggunakan instrument penelitian berupa kuesioner baik pada dukungan suami maupun pemilihan kontrasepsi. Pengelolaan dan analisa data menggunakan program SPSS dan selanjutnya disajikan dalam bentuk tabel dan narasi, dengan menggunakan tes statistik dengan tingkat kemaknaan $\alpha<$ 0,05

Dari tabel 4.1 diperoleh bahwa responden yang tidak didukung oleh suaminya sebanyak 33 orang $(61.1 \%)$ dan yang mendukung sebanyak 21 orang $(38,9 \%)$. Berdasarkan hasil penelitian yang dilakukan mayoritas ibu yang berKB tidak didukung oleh suaminya sebanyak 33 orang $(61.1 \%)$. 
Tabel $\quad 4.2 \quad$ Distribusi $\quad$ Frekuensi Berdasarkan Pemilihan Kontrasepsi

\begin{tabular}{ccc}
\hline $\begin{array}{c}\text { Pemilihan } \\
\text { Kontrasep } \\
\text { si }\end{array}$ & $\begin{array}{c}\text { Frekuens } \\
\mathbf{i}\end{array}$ & $\begin{array}{c}\text { Persentas } \\
\mathbf{i}\end{array}$ \\
\hline IUD & 20 & 37.0 \\
Non IUD & 34 & 63.0 \\
\hline Total & 54 & 100.0 \\
\hline
\end{tabular}

Dari tabel 4.2 diperoleh bahwa responden yang memilih kontrasepsi Non IUD sebanyak 34 orang (63.0\%) dan yang memilih kontrasepsi IUD sebanyak 20 orang (37.0\%). Berdasarkan hasil penelitian yang dilakukan mayoritas akseptor $\mathrm{KB}$ memilih memakai kontrasepsi Non IUD sebanyak 34 orang $(63.0 \%)$

Tabel 4.3 Hubungan Dukungan Suami terhadap Pemilihan kontrasepsi IUD di Puskesmas Mamburungan Kota Tarakan

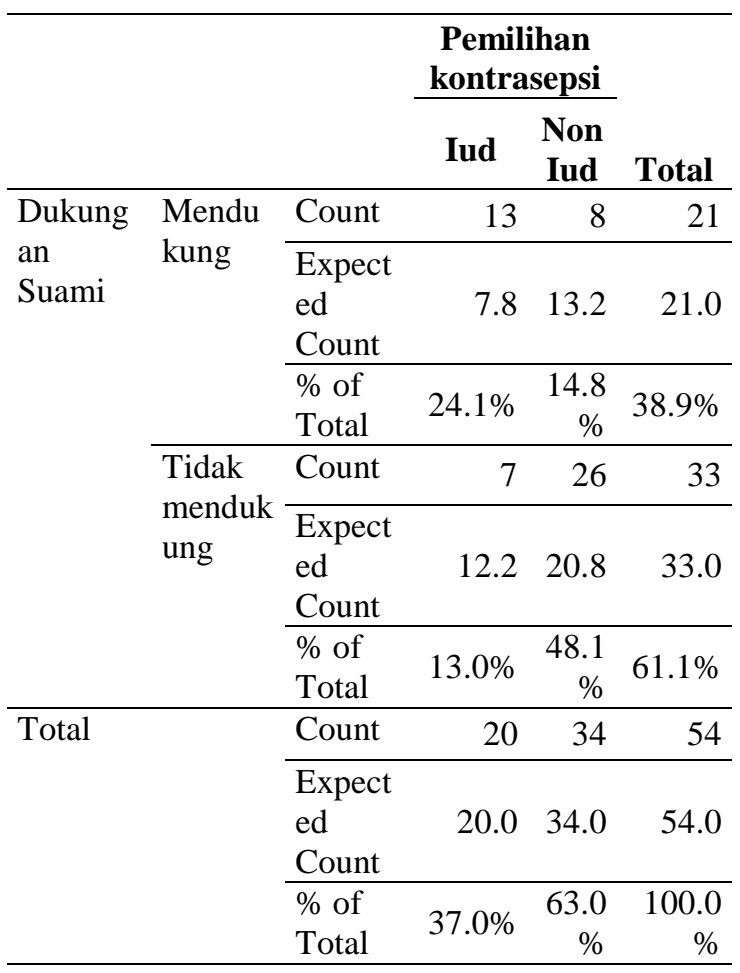

Berdasarkan tabel 4.3 sebagian besar responden tidak mendapatkan dukungan suami dan tidak memilih kontrasepsi IUD sebanyak 26 responden $(48,1 \%)$, kemudian responden yang tidak mendapatkan dukungan suami dan memilih kontrasepsi IUD sebanyak 7 responden $\quad(13,0 \%)$. Sedangkan responden mendapatkan dukungan suami dan memilih kontrasepsi IUD sebanyak 13 responden $(24,1 \%)$, kemudian responden yang mendapatkan dukungan suami tetapi tidak memilih kontrasepsi IUD sebanyak 8 responden $(14,8 \%)$.

Tabel 4.4 Hasil uji Chi-Square Hubungan dukungan suami terhadap pemilihan kontrasepsi IUD

Chi-Square Tests

\begin{tabular}{|c|c|c|c|c|c|}
\hline & $\begin{array}{c}\text { Valu } \\
\text { e }\end{array}$ & df & $\begin{array}{c}\text { Asym } \\
\text { p. } \\
\text { Sig. } \\
\text { (2- } \\
\text { sided) }\end{array}$ & $\begin{array}{c}\text { Exact } \\
\text { Sig. } \\
(2- \\
\text { sided })\end{array}$ & $\begin{array}{c}\text { Exact } \\
\text { Sig. } \\
(1- \\
\text { sided) }\end{array}$ \\
\hline $\begin{array}{l}\text { Pearson } \\
\text { Chi-Square }\end{array}$ & $\begin{array}{r}9.11 \\
3^{\mathrm{a}}\end{array}$ & 1 & .003 & & \\
\hline $\begin{array}{l}\text { Continuity } \\
\text { Correction }^{b}\end{array}$ & $\begin{array}{r}7.45 \\
1\end{array}$ & 1 & .006 & & \\
\hline $\begin{array}{l}\text { Likelihood } \\
\text { Ratio }\end{array}$ & $\begin{array}{r}9.17 \\
3 \\
\end{array}$ & 1 & .002 & & \\
\hline $\begin{array}{l}\text { Fisher's } \\
\text { Exact Test }\end{array}$ & & & & .004 & .003 \\
\hline $\begin{array}{l}\text { Linear-by- } \\
\text { Linear } \\
\text { Associatio } \\
n\end{array}$ & $\begin{array}{r}8.94 \\
4\end{array}$ & 1 & .003 & & \\
\hline $\begin{array}{l}\mathrm{N} \text { of Valid } \\
\text { Cases }\end{array}$ & 54 & & & & \\
\hline
\end{tabular}


Dari hasil uji Chi-Square menunjukkan bahwa Asymp, Sig yaitu 0,006 yang berarti $\rho$ value $<0,05$. Hal ini menunjukkan $\mathrm{H}_{0}$ ditolak dan $\mathrm{H}_{\mathrm{a}}$ diterima. Maka dapat disimpulkan bahwa ada hubungan yang signifikan antara hubungan dukungan suami terhadap pemilihan KB IUD di Puskesmas Mamburungan Kota Tarakan.

\section{Pembahasan}

\section{A. Dukungan suami terhadap pemilihan kontrasepsi}

Dukungan adalah menyediakan sesuatu untuk memenuhi kebutuhan orang lain. Dukungan juga dapat diartikan sebagai memberikan dorongan/ motivasi atau semangat dan nasihat kepada orang lain dalam situasi pembuat keputusan (Notoatmodjo, 2003). Dukungan suami sangatlah berdampak positif bagi keluarga terlebih dengan pasangannya, karena adanya dukungan suami terutama dalam pemilihan IUD, maka istri akan merasa percaya diri dalam memilih dan selama pemakaiannya istri tidak akan khawatir karena telah mendapat dukungan oleh suami. (Jacinta, 2007).

Hal ini menunjukkan bahwa teori dan hasil penelitian hampir memiliki kesamaan, dukungan suami merupakan salah satu faktor utama yang mempengaruhi pemilihan kontrasepsi. Bagi ibu, dukungan suami terhadap ibu sikap yang harus dikembangkan, karena pada hakikatnya dukungan suami sangatlah berdampak positif bagi sang istri. Hasil penelitian yang telah dilakukan menunjukkan 33 responden (61.1\%) yang tidak mendapatkan dukungan pada suaminya untuk memilih kontrasepsi IUD dan Non IUD serta diantaranya yang suaminya mendukung dalam pemilihan kontrasepsi 21 responden $(38,9 \%)$. Hal ini disebabkan karena sebagian besar ibu yang ber KB tidak didukung oleh suaminya untuk memakai kontrasepsi IUD maupun Non IUD, karena dukungan suami sangatlah berdampak positif bagi keluarga, terlebih dengan pasangannya, karena adanya dukungan suami terutama dalam pemilihan IUD, kemudian istri akan merasa lebih percaya diri dalam memilih dan selama pemakaiannya istri tidak akan khawatir karena suami telah mendukung.

Hal tersebut merupakan dukungan yang dapat diberikan suami kepada istri. Masalah kontrasepsi bukanlah tanggung jawab istri semata, tetapi merupakan tanggung jawab suami juga. Apabila 
seorang istri menginginkan untuk menggunakan IUD sebagai alat kontrasepsi yang akan digunakan, maka seorang suami harus bisa memberikan tanggapan yang positif dan mampu memberikan dukungan. Apabila suami tidak memberikan dukungan maka seorang istri tidak akan menggunakan kontrasepsi yang menjadi pilihannya yaitu IUD. Dukungan seorang suami merupakan bentuk motivasi yang diberikan kepada istri. Jika suami memberikan motivasi maka sorang istri secara tidak langsung akan merasa bahagia.

\section{B. Pemilihan kontrasepsi}

Penggunaan kontrasepsi merupakan tanggung jawab bersama antara pria dan wanita sebagai pasangan, sehingga metode kontrasepsi yang dipilih mencerminkan kebutuhan serta keinginan bersama. Dalam hal ini bisa saja pria yang memakai kontrasepsi seperti kondom, coitus interuptus dan vasektomi, suami mempunyai tanggung jawab utama. Sementara bila istri sebagai pengguna kontrasepsi suami mempunyai peranan penting dalam mendukung istri dan menjamin efektivitas pemakaian kontrasepsi. (Saifuddin, 2003)
IUD (Intra Uterin Device atau Alat Kontrasespsi Dalam Rahim) merupakan alat kontrasepsi yang makin popular yang telah digunakan selama lebih dari 30 tahun. Kebanyakan wanita menganggap alat kontrasepsi ini sangat efektif dan mudah pemakaiannya. Alat kontrasepsi dalam rahim merupakan pilihan kontrasepsi yang efektif, aman dan nyaman bagi banyak wanita. Alat ini merupakan metode kontrasepsi reversible yang paling sering digunakan diseluruh dunia dengan pemakai mencapai sekitar 100 juta wanita. (Irianto, 2014)

Pemilihan kontrasepsi IUD maupun Non IUD pada akseptor KB di wilayah kerja Puskesmas Mamburungan menunjukkan bahwa responden yang memilih kontrasepsi Non IUD sebanyak 34 orang $(63.0 \%)$ dan yang memilih kontrasepsi IUD sebanyak 20 orang (37.0\%). Berdasarkan hasil penelitian yang dilakukan mayoritas akseptor $\mathrm{KB}$ memilih memakai kontrasepsi Non IUD sebanyak 34 orang $(63.0 \%)$.

Hubungan seorang wanita dengan pasangannya dapat menjadi faktor dalam menentukan pemilihan kontrasepsi tertentu. Karena pada banyak masyarakat, pasangan yang tidak saling berkomunikasi tentang keluarga 
berencana, pihak wanitalah yang sering kali harus memperoleh dan menggunakan alat kontrasepsi bila ingin mengatur jarak anak.

Responden yang tidak mendapatkan dukungan suami cenderung mempunyai minat yang rendah dalam pemakaian kontrasepsi IUD. Penggunaan kontrasepsi merupakan kebutuhan antara suami dan istri. Sehingga dalam menentukan kontrasepsi apa yang akan digunakan seorang suami mempunyai hak untuk ikut menentukan. Suami harus dapat memberikan berbagai informasi tentang alat kontrasepsi kepada istri, mempunyai pengetahuan yang cukup baik tentang alat kontrasepsi, bersedia membantu istri dalam memilih alat kontrasepsi dan mampu memberikan saran yang baik, bersedia mengantar dan mendampingi istri dalam konsultasi, bersedia memberikan biaya untuk pemasangan kontrasepsi yang akan digunakan dan bersedia untuk mencarikan pertolongan apabila istri mengalami masalah atau komplikasi dalam pemakaian kontrasepsi.

Berdasarkan Hasil penelitian Aniswatin Sa'adah (2013) tentang dukungan suami dengan pemilihan alat kontrasepsi IUD dapat diketahui bahwa ibu dengan dukungan suami yang tidak mendukung pemilihan alat kontrasepsi IUD lebih banyak berjumlah 33 responden dengan kriteria tidak mendukung alat kontrasepsi IUD sebanyak 27 responden (81,8\%), yang memilih alat kontrasepsi IUD hanya 6 responden $(41,1 \%)$, sedangkan ibu dengan dukungan suami yang mendukung dalam pemilihan alat kontrasepsi IUD berjumlah 21 responden dengan kriteria memilih alat kontrasepsi IUD sebanyak 17 responden (81\%) sedangkan yang tidak memilih sebanyak 4 (19\%). Dukungan suami merupakan sifat interaksi yang berlangsung dalam berbagai hubungan sosial individu, yaitu istri. Sudah menjadi tradisi kalau segala sesuatu harus dengan persetujuan suami atau yang berkuasa di rumah. Hal ini sangat mempengaruhi seorang ibu untuk menjadi seorang akseptor. Keluarga sangat berperan penting dalam pemilihan alat kontrasepsi, karena jika ada salah satu keluarga yang tidak setuju, ibu akan mempertimbangkan ulang pilihannya misalnya ibu memilih IUD dan sebagian besar ibu akan ikut dengan keputusan suami, atau anggota keluarga yang lain. 
Pada hasil penelitian ini menggunakan analisa bivariat menunjukkan nilai $\rho$ value 0.006 yang artingan nilai $\rho$ value $<0,05$, artinya $\mathrm{H}_{\mathrm{a}}$ diterima dan $\mathrm{H}_{0}$ ditolak. Yang menunjukkan bahwa terdapat hubungan yang signifikan antara dukungan suami terhadap pemilihan KB IUD. Dari 54 responden lebih banyak responden yang tidak di dukung oleh suaminya. Akan tetapi dari 54 responden terdapat 21 responden yang dapat dukungan dari suaminya dikarenakan suami ingin memberi jarak anaknya. Dalam penelitian ini menggunakan Proportionate Stratified Random Sampling karena keterbatasan dan kemampuan peneliti, sehingga dalam melakukan penelitian selama 8 hari untuk mendatangi rumah-rumah warga, peneliti hanya mendapatkan 33

\section{Kesimpulan}

Berdasarkan hasil uji statistik dengan menggunakan chi-quare test hubungan dukungan suami terhadap pemilihan KB IUD, hasil uji chi-quare test menunjukkan bahwa $\rho$ value 0,006 dimana $\rho$ value $<0,05$, sehingga hipotesa alternatif $\left(\mathrm{H}_{\mathrm{a}}\right)$ diterima yang berarti bahwa terdapat hubungan yang signifikan antara hubungan dukungan suami terhadap pemilihan KB IUD. responden yang tidak mendapatkan dukungan oleh suaminya dan 21 diantaranya mendapatkan dukungan oleh suaminya terhadap pemilihan kontrasepsi.

Hal ini dapat disebabkan dukungan suami dalam ber-KB dapat ditunjukkan dengan membantu memilih kontrasepsi yang sesuai dengan keinginan dan kondisi istrinya, menggunakan kontrasepsi dengan benar, mencari pertolongan jika terjadi efek samping maupun komplikasi sesudah pemasangan IUD, mengantar istri ke tempat pelayanan kesehatan untuk kontrol ulang, membantu mencari alternatif lain jika IUD terbukti tidak memuaskan dan bersedia menggantikan istri jika kondisi istri tidak memungkinkan untuk menggunakan kontrasepsi.

Diharapkan hasil penelitian ini kepada petugas kesehatan lebih sering memberikan penyuluhan dan konseling tentang KB IUD dengan didampingi oleh suaminya agar suami juga mengerti kontrasepsi apa yang tepat untuk istri dan suami, bagi pengguna kontrasepsi IUD diharapkan dapat menambah pengetahuan ibu tentang hubungan 
dukungan suami terhadap pemilihan kontrasepsi.

\section{Referensi}

BKKBN. (2011). Kebijakan Teknis Penanggulan Masalah Kesehatan Reproduksi Melalui Program KB Nasional. Jakarta.

Chaerunnisa AR. (2014) Relationship between Pregnant Women Behavior to Antenatal Care Utilization at Mamajang Health Center Makassar City.

Depkes. (2000). Program Keluarga Berencana. Diambil dari http://www.depkes.go.id.

Fajrin Nurul. (2014). Faktor-faktor yang Mempengaruhi Penggunan Alat Kontrasepsi IUD pada Pasangan Usia Subur di Puskesmas Limba B Kecamatan Kota Selatan Kota Gorontalo. Other thesis. Gorontalo: Universitas Negeri Gorontalo.

Fatimah Dewi. (2013). Faktor-faktor yang berhubungan dengan penggunaan Alat Kontrasepsi Dalam Rahim (AKDR) di Wilayah Kerja Puskesmas Kecamatan Pasar Rebo Jakarta Timur.Tesis. Jakarta: Universitas Islam Negeri.
Glasier, A and Ailsa, G. (2012). Keluarga Berencana Dan Kesehatan Reproduksi Edisi 4. Jakarta: EGC.

Hartanto, Hanafi. (2004). Keluarga Berencana Dan Kotrasepsi. Jakarta: Pustaka Sinar Harapan. Irianto Koes. (2014). Pelayanan Keluarga Berencana. Alfabeta: Bandung.

Jacinta. (2007). Partisipasi Pria dalam Ber-KB. Diambil dari http://www.psikiater-rakyat.

Manuaba, Ida Ayu Chandradinata. (2009) Memahami Kesehatan Reproduksi Wanita. Cetakan I. Jakarta: EGC.

Manuaba, I.B.G. (1998). Ilmu Kebidanan, Penyakit Kandungan dan KeluargaBerencana Untuk Pendidikan Bidan. Jakarta, EGC. Manuaba, Ida Bagus. (2009) Ilmu Kebidanan, Penyakit Kandungan dan KB. Jakarta: EGC.

Notoatmodjo, S. (2005). Metodologi Penelitian Kesehatan. Rhineke Cipta.

Notoatmodjo, S. (2003). Ilmu Kesehatan Masyarakat. Jakarta: Rineka Cipta. 
Retnowati, Y.,Novianti, D.\&Wulandary, K., Dukungan Suami Terhadap Pemilihan Kontrasepsi Intrauterin Device Di Wilayah Kerja Puskesmas Mamburungan

Notoatmodjo, S. (2012). Metodologi

Penelitian Kesehatan. Jakarta:

Rineka Cipta.

Rachmayani Noor Asiva. (2015).

Faktor-faktor yang berhubungan

dengan perilaku penggunaan

kontrasepsi pada WUS di

Provinsi Sumatera Utara. Tesis.

Jakarta: Universitas Islam

Negeri.

Saifuddin Abdul Bari, dkk. (2006). Buku

Panduan Praktis Pelayanan

Kontrasepsi. Jakarta: Yayasan

Bina Pustaka Sarwono

Prawirohardjo.

Saifuddin (2003). Buku Acuan

Pelayanan Kesehatan Maternal dan Neonatal. KNPKKR-POGI, Jakarta.

Saifuddin Abdul Bari, dkk. (2006). Buku

Panduan Praktis Pelayanan

Kontrasepsi. Jakarta: Yayasan

Bina Pustaka Sarwono

Prawirohardjo.

Winda, Nova. (2011). Faktor-faktor yang Mempengaruhi Rendahnya Minat Ibu Menggunakan Metode Kontrasepsi AKDR di Desa Kedai Damar Kecamatan Tebing Tinggi. Skripsi. Sumatera Utara: Fakultas Keperawatan Universitas Sumatera Utara. 